\title{
RECENT RESEARCH QUESTIONS OF ECOLOGICAL ASPECTS OF THE INTERACTION OF THE ORGANISM AND THE ENVIRONMENT
}

\author{
(C) Vladimir M. Evstropov, Ekaterina A. Trushkova, Alena V. Nikhayeva
}

\author{
Don State Technical University, Rostov-on-Don, Russian Federation \\ v.evstr@mail.ru, rudenko-centr@mail.ru, ecolog-1@mail.ru
}

For a single organism, the characteristics of levels of organization of living matter are the following: molecular-gene, supramolecular, cellular, tissular, and organ ones. Organismic, population-species, and biocenotic levels of organization of living matter are characteristic of a set of organisms. Organisms can also act as an environmental factor. Nanobacteria, widely distributed in environmental compartments (in particular in water), can initiate various diseases in humans and are a new environmental factor (a bioindicator of ecological problems in the environment). The presence of organisms of some other species (staphylococci, salmonella, ETEC) in surface waters has also unfavorable nature and is a criterion of sanitary-hygienic assessment of the epidemic hazard of these waters, testifying to the unfavorable environmental situation. Moreover, vice versa, organisms (biota) can clean and heal water bodies thanks to the processes of phytoremediation, bioremediation and zooremediation. The environment is considered as a complex of natural bodies and phenomena with which the body is in direct or indirect relationships, as part of nature, surrounding a living organism and having a direct or indirect effect on its state and functioning (growth, development, survival, reproduction, etc. ) The habitat is a combination of objects, phenomena and environmental factors that determines the living conditions of living creatures, natural conditions in all the same habitats. According to the qualitative specificity of the complexes of conditions providing an opportunity for life, they distinguish living environments mastered by living organisms: water, land (air-ground living environment), soil and organism (for parasites and symbionts). Moreover, organisms exist in one or more environments of life. Organisms living in the internal environment of the host organism (blood, lymph, tissue) underwent significant adaptation and protective modifications: co-adaptation of the parasite and the host, symbionts to each other, the formation of the parasite's protection against digestion by the host and the system of local fixation in the environment, strengthening sexual reproduction, reduction of vision and digestive system, synchronization of biorhythms with biorhythms of the host organism. There are two strategies for the development of living creatures: the r-strategy, which implies rapid reproduction and short life, and the k-strategy, which is characterized by a low rate of reproduction and long life. In accordance with the r-strategy, the population develops in adverse environmental conditions, but the frequent generational changes that occur at the same time contribute to the consolidation of useful mutations that allow the most successful resistance to adverse effects.

Key words: ecology, organism, environment, environmental factor, adaptation.

[В.М. Евстропов, Е.А. Трушкова, А.В. Нихаева Актуальные вопросы исследования экологических аспектов взаимодействия организма и окружающей среды]

Для отдельно взятого организма характерны следующие уровни организации живого вещества: молекулярно-генный, надмолекулярный, клеточный, тканевый, органный. Организменный, популяционно-видовой и биоценотический уровни организации живого вещества характерны для совокупности организмов. Организмы могут выступать и в роли экологического фрактора. Нанобактерии, широко распространенные в объектах окружающей среды (в частности в воде), могут инициировать у человека различные заболевания и являются новым экологическим фрактором (биоиндикатором экологического неблагополучия среды. Наличие организмов некоторых других видов (стафилококки, сальмонеллы, кишечная палочка) в поверхностных водах также носит неблагоприятный характер и является критерием санитарно-гигиенической оценки эпидемической опасности этих вод, свидетельствуя о неблагоприятной экологической обстановке. И наоборот, организмы (биота) могут очищать и оздоравливать водоемы, благодаря процессам фриторемедиации, биоремедиации и зооремедиации. Среда рассматривается как комплекс природных тел и явлений, с которыми организм находится в прямых или косвенных взаимоотношениях, как часть природы, окружающую живой организм и оказывающую прямое или косвенное воздействие на его состояние и функционирование (рост, развитие, выживание, размножение и т.д.). Среда обитания представляет собой совокупность 
объектов, явлений и фракторов окружающей среды, определяющая условия жизнедеятельности живых существ, природные условия во всех однотипных местообитаниях. По качественной специфике комплексов условий, обеспечивающих возможность для жизни, различают среды жизни, освоенные живыми организмами: вода, суша (наземно-воздушная среда жизни), почва и организм (для паразитов и симбионтов). Причем организмы существуют в одной или нескольких средах жизни. Организмы, живущие во внутренней среде организма-хозяина (кровь, лимфа, ткани), подверглись существенной модификации адаптационного и защитного характера: коадаптация паразита и хозяина, симбионтов друг к другу, формирование у паразита защиты от переваривания хозяином и системы локальной фиксации в среде, усиление полового размножения, редукция зрения и пищеварительной системы, синхронизация биоритмов с биоритмами организма хозяина. Существует две стратегии развития живых существ: r-стратегия, предполагающая бурное размножение и короткую жизнь, и k-стратегия, для которой характерен низкий темп размножения и долгая жизнь. В соответствии с r-стратегией популяция развивается в неблагоприятных условиях среды, но происходящая при этом частая смена поколений способствует закреплению полезных мутаций, которые позволяют наиболее успешно противостоять неблагоприятным воздействиям.

Ключевые слова: экология, организм, среда, экологический фактор, адаптация.

Vladimir M. Evstropov - M. D., Associate Professor, Professor, "Safety of Engineering Procedures and Productions" department, Don State Technical University, Rostov-on-Don, Russian Federation.

Ekaterina A. Trushkova - Ph.D. in Technical Sciences, Associate Professor, "Safety of Engineering Procedures and Productions" department, Don State Technical University, Rostov-on-Don, Russian Federation.

Alena V. Nikhayeva - Ph.D. in Technical Sciences, Associate Professor, "Safety of Engineering Procedures and Productions" department, Don State Technical University, Rostov-on-Don, Russian Federation.

Евстропов Владимир Михайлович - доктор медицинских наук, доцент, Донской государственный технический университет, г. Ростов-на-Дону, Российская Федерация.

Трушкова Екатерина Алексеевна - кандидат технических наук, доцент, Донской государственный технический университет, г. Ростов-на-Дону, Российская Федерация.

Нихаева Алена Владимировна - кандидат технических наук, доцент, Донской государственный технический университет, г. Ростов-на-Дону, Российская Федерация.

All organisms are united by the fact that they are represented by living matter, which has different levels of organization, represented by organisms or their combination.

1. Molecular gene (suborganismic) - a special form of organization of living inherent in all organisms - a set of organic and inorganic substances interconnected by a specific structure and system of biochemical processes, capable of growth, development, selfpreservation, and reproduction throughout the life of this organism.

2. The supramolecular (subcellular) level is characterized by the fact that the molecules of various substances form the organelles of the cell, each of which has a specific structure and function.

3. Cellular level means that cells have a strictly defined structure inherent in both organisms from the plant kingdom and organisms from the animal kingdoms and mushrooms.

4. The tissular level is characteristic of complex multicellular organisms in which cells have specialized in the functions performed and tissue formation is a set of cells having the same origin, similar structure and performing the same or similar functions.

5. The organ level is characteristic of highly organized organisms; tissues form structures designed to perform certain functions (organs).

6 . The organismic level is characterized by the union of organ systems into a single whole (organism), the functioning of which implements the vital activity of a particular living creature. 
7. The population-species level is represented by groups of individuals of one species living in a given specific territory and occupying a certain ecological niche (population), and populations of the same organisms form subspecies and species.

8. Biocenotic level is a set of populations of different species living in the same territory and interacting with each other (biocenosis).

For a single organism, the characteristics of levels of organization of living matter are the following: molecular-gene, supramolecular, cellular, tissular, and organ ones. Organismic, population-species, and biocenotic levels of organization of living matter are characteristic of a set of organisms [25].

Organisms can also act as an environmental factor. According to researchers [7, $\mathrm{p}$. 27], nanobacteria, widely distributed in environmental objects (in particular in water), can initiate various diseases in humans and are a new environmental factor (bioindicator of ecological problems in the environment [28].

The fact that nanobacteria are living particles is evidenced by their ability to increase the growth rate under the action of sunlight [40]. In addition, the researchers were able to carry out PCR $16 S$ r DNA and not without reason to suggest that nanobacteria belong to the alpha-2 subgroup of Proteobacteria, which includes such genera as Brucella and Bartonella [40].

The presence of organisms of some other species (staphylococci, salmonella, E. coli) in surface waters is also unfavorable and is a criterion of sanitary-hygienic assessment of the epidemic danger of these waters, indicating an unfavorable environmental situation (ecological emergency, ecological disaster, etc.) [29, p. 9]. Moreover, vice versa, organisms (biota) can clean and heal water bodies (phytoremediation, bioremediation, zooremediation) [21].

Autecology in the form of a section of Ecology studies the influence of environmental factors on individual organisms; establishes the limits of the existence of an organism in the environment, examines the reactions of organisms to the effects of environmental factors, their adaptability to environmental conditions. Autecology studies a living organism as a living system, and everything that surrounds it as an environment. In the aspect of factorial ecology, the environment is understood as a complex of natural bodies and phenomena with which the organism is in direct or indirect relationships [8]. A.S. Stepanovskikh adheres to a similar point of view [28], considering the environment as a part of nature, surrounding living organisms and exerting a direct or indirect effect on them.

M. Bigon et al. taking into account the environmental characteristics of individuals, populations and communities conclude that the environment is everything that surrounds the organism and directly or indirectly affects its state and functioning (growth, development, survival, reproduction, etc. . .) [5]. A similar point of view is held by G.S. Rosenberg and F.N. Ryanskiy, it is believed that ecology is a biological discipline that studies the relationships of organisms and the environment that determine the lifestyle: reproduction, nutrition, survival, abundance and distribution of animals [23]. E. Haeckel considers ecology to be a general science about the attitude of the organism to the environment (conditions of existence) [38]. According to G.L. Clarke, modern ecology deals with the functional interdependence between living things and their environment [38]. R. Margalef also emphasizes that ecology studies systems at the level at which individuals organisms are considered as elements interacting with each other or with the environment [38]. In the modern interpretation of ecology that is popular in the last decades of the $X X$ century, the subject of ecology is considered as set or structure of relations between organisms and their environment (environmental biology) [20]. It is fair to say that I.V. Krut and I.M. Zabelin have proposed to call organism-centric ecology more particularly bioecology [18]. 
The environment is often understood as the part of nature that surrounds organisms and has a direct or indirect effect on them. From the environment, species receive everything necessary for life while emitting the products of their metabolism into it. By definition of $\mathrm{N}$. P. Naumov (1963), the environment is called "everything that surrounds organisms directly and indirectly affects their condition, development, survival and reproduction" [19].

According to the qualitative specificity of the complexes of conditions providing an opportunity for life, A.K. Brodsky (2000) distinguishes living environments developed by living organisms: water as a living environment, land (land-air living environment), soil and organism (for parasites and symbionts). Moreover, organisms exist in one or more environments of life. Most species of gymnosperms and angiosperms, birds, mammals, humans, etc. are inhabitants of only the terrestrial air environment. Many insects (mosquitoes, dragonflies, and mayflies), amphibians, etc. go through one phase of their development in the aquatic, and the other in the ground-air environment. There are insects (cockchafer, rose chafer, click beetles, etc.) that need ground-air and soil environments for their life [6].

When adapting to the aquatic environment, some body features are formed: streamlined body shape, buoyancy, mucous membranes, development of airways, osmoregulation, and poor protection against evaporation. Organisms living in the soil environment are characterized by a swollen body shape, mucous membranes or a smooth surface; some have a digger, well-developed muscles, and small sizes that contribute to adaptation to life in film water or in air pores. In the process of adaptation to its conditions, ground-air organisms developed a supporting skeleton, formed mechanisms for regulating the hydrothermal regime, as well as releasing the sexual process from the liquid medium. Organisms living in the internal liquid or dense medium of the host organism (blood, lymph, tissue) underwent significant adaptive and protective modifications: coadaptation of the parasite and the host, symbionts to each other, formation of protection against digestion by the parasite and the local fixation system in environment, increased sexual reproduction, reduction of vision and digestive system, synchronization of biorhythms with biorhythms of the host [8].

The organism, as a habitat, was considered primarily by parasitologists [22]. The use by some living organisms of others as a habitat is widespread in nature. Multicellular organisms of any kind have internal inhabitants, but the ability to use other organisms as a habitat as a whole decreases with the complexity of their organization. Therefore, parasites are most common among microorganisms and relatively primitive multicellular organisms, and vertebrate animals are most exposed to parasitic infections. The ecological advantages of the inhabitants of living organisms include practically unlimited food resources and protection from the direct impact of environmental factors. Inside the owner, its roommates practically do not encounter the threat of drying out, sharp fluctuations in temperature, significant changes in the salt and osmotic regimes, etc.

These conditions do not stimulate the differentiation of the body; therefore, many internal parasites and symbionts are characterized in evolution by a secondary simplification of the structure, sometimes losing entire organ systems. Cohabitants of living organisms also encounter environmental difficulties, the main of which are the limited living space for tissue and especially intracellular inhabitants, the difficulty of oxygen supply, the difficulty of spreading from one host to another, and the host's protective reactions against parasites. In addition, the habitat of parasites is limited by the period of the host's life, and in the spatial boundaries of his body. Often parasites themselves become the habitat of other species hyperparasitism (superparasitism) occurs, which can be two-, three- and four-stage [34, p. 33]. 
An organism of blood-sucking arthropods was successfully used as a model for studying the organism as a habitat [2]. They have some features of the internal environment that determine the possibility of development and completion of the life cycle phase of pathogens of humans and animals. The main types of use of arthropod pathogens as a habitat include not only helminths and protozoa, but also bacteria, arboviruses, rickettsia and spirochetes. Exploring the levels of use of pathogens of the body of arthropods as a habitat, A.N. Alekseev and Z.N. Kondrashova (1985) analyze epithelial cells from the perspective of the microenvironment of pathogens. It is clear that for them, the microenvironment can be considered as a microenvironment that directly affects the vital activity of pathogens.

This coordinated and interconnected activity of the living organisms of the Earth is in the closest connection with the environment and its main factors of a physical, chemical, biological nature and creates an ecological system - a complex construction of life in its various manifestations. O.L. Voskresenskaya et al. (2005), apparently considering the organism from a systemic ecological-biological position, draw attention to the fact that:

a) the organism is an element of the biosphere as a holistic global ecological system;

b) the biosphere as an integrated global ecological system has a certain structure and stability, its inherent features of formation and development.

However, there is another point of view regarding the interpretation of the concepts "environment of life", "environment" and "sphere of life" [30]. Based on the vital activity of living beings as a system-forming element of the structure of a concept, V.F. Khabibullin believes that the habitat is a combination of objects, phenomena and environmental factors that determines the living conditions of living creatures, natural conditions in all the same type of ecotopes (habitats). By habitat, the author understands the environment that directly surrounds the body in which its vital activity takes place.

The habitat is implemented by a specific set of ecotopes, while the soil is considered by V.F. Khabibullin as a habitat, but not as a living environment. The classification of habitats and spheres of life proceeds from the aggregate state of the main substance (matrix) that forms this environment (gaseous - typical for the air-ground living environment; liquid - for the aquatic living environment; solid state - for the "underground" - substrate - living environment). Spheres of life can be considered in the form of: a) the ontosphere i.e. part of the biosphere, including organisms and their living (organism) environment; b) the geobiosphere i.e. part of the biosphere, including organisms and their abiotic environment.

The environment of each organism is composed of many elements of an inorganic and organic nature and elements brought in from outside, the human body environment is also adjusted by the elements brought in during its production activities. At the same time, some elements may be partially or completely indifferent to the body, others are necessary, and still others have a negative effect. With the elements of the environment necessary for the existence of the organism, the concept of "living conditions" or "conditions of existence" is closely related.

An ecological factor is an element or environmental parameter that can affect living organisms and directly affect the nature and intensity of processes occurring in an ecosystem. Living organisms respond to environmental factors with evolutionarily acquired adaptive responses. Ecological factors of habitat are divided into main groups: abiotic, biotic and anthropogenic factors [34].

Some features are influenced by environmental factors (environmental parameters) on isolated cells of a multicellular organism in an artificial environment, in particular, when cells are cultured in 199 in vitro medium [10, p. 11]. With a change in the temperature conditions of cell cultivation, the cytoarchitectonics of intercellular interactions in vitro was changing [12]. 
The study of evolution is given fundamental importance in science. E.N. Knyazeva believes that in science, everything makes sense only in the light of evolution [14], and the idea of evolution, directly connected with the idea of ecology, has extraordinary power [15]. The author understands evolution in several senses: a) as global evolution, b) as coevolution, c) as an organization of ecological niches.

Interesting patterns were revealed in the analysis of the influence of the environment on the evolution of living things. The researchers described the existence of two strategies for the development of living things: the r-strategy, which implies rapid reproduction and short life, and the k-strategy, which is characterized by a low rate of reproduction and a long life. In accordance with the r-strategy, the population develops in adverse environmental conditions, but the frequent generational change that occurs contributes to the consolidation of useful mutations that allow the most successful resistance to adverse effects [38, p. 4].

It is known that the elemental composition of living organisms depends on the content of chemical elements in the environment [13]. A sharp change (deficit or excess) of elements in the environment leads to diseases of plants, animals, humans. These diseases are treated as biogeochemical endemia, and their distribution areas are called biogeochemical provinces [3]. However, the biological reactions of organisms to changes in geochemical factors can be manifested not only in the occurrence of endemic diseases, but also in tolerance (adaptability), the formation of new species, subspecies; deformities and death of organisms [1, p.16, p. 26].

Three types of biogeochemical provinces should be distinguished: 1) natural; 2) technogenic; 3) mixed. Natural biogeochemical provinces are areas on the Earth within which the biological reactions of living organisms are determined by abnormal levels of the content and ratio of natural bioelements. Zonal natural biogeochemical provinces are characterized by levels and ratios of bioelements typical for the whole subregion with unidirectional biological reactivity in all living organisms of the biosphere, while azonal natural biogeochemical provinces are atypical for the whole subregion and have ratios of bioelements with atypical manifestations of many biological reactions living organisms of the biosphere [24].

From ecological point of view, the main functions of the chemicals involved in nontrophic interactions are distinguished. 1. Protection from a potential predator: its deterrence, elimination, (many toxic or repellent substances of plants, substances with hormonal effects, "defensive" excreta and invertebrate toxins). 2. The property of offensive biochemical weapons (toxins and ecoenzymes of parasitic fungi, pathogenic bacteria, as well as toxins of predatory animals. 3. Containment of competitors of the same trophic level - both defensive and offensive function (lower and higher plants). 4. Attraction, luring with the help of attractants that stimulate food, motor or reproductive activity (various types of ecochemomediators) 5. Regulation of interactions within populations, groups, individuals or families using substances that regulate their behavior and reproductive activity in many vertebrates. 6 . Supply of the organisms that perceive these substances with the necessary molecules from which hormones or pheromones are created, or with the molecules used by the receptive organism in its finished form. 7. Participation in the formation of the environment (components of soluble organic matter released by hydrobiont). 8. Indication of habitats suitable for settlement, colonization or reproduction, spatial orientation and formation of preferences when searching for habitats (all mobile organisms) [17].

Thus, the environmental aspects of the interaction of organisms and the environment can be considered from the standpoint of: a) ecological and biological classification of organisms (living matter with different levels of organization); b) characteristics of organisms as an environmental factor; c) environmental classification and environmental characteristics; d) studying the influence of environmental factors on individual organisms, 
establishing the limits of the existence of an organism in the environment: studying the reactions of organisms to the effects of environmental factors, their adaptability to environmental conditions; e) the influence of environmental factors on the evolution of living things; e) the study of ecological systems with artificial environment.

\section{Лumepamypa}

1. Авцын А.П., Жаворонков А.А., Риш М.А., Строчкова Л.С. Микроэлементозы человека: этиология, классификация, органопатология. М.: Медицина, 1991. 496 C.

2. Алексеев А.Н., Кондрашова 3.Н. Организм членистоногих как среда обитания возбудителей. Свердловск: УНЦ АН СССР, 1985.180 с.

3. Безуглова О.С., Орлов Д.С. Биогеохимия. Ростов н/Д: Феникс, 2000. 320 с.

4. Белов С.В. Эволюция организмов и основной парадокс экологии // Экологические системы и приборы. 2018. № 2. С. 3-9.

5. Бигон М., Харпер Дж., Таунсенд К. Экология. Особи, популяции и сообщества. М.: Мир, 1989. Т 1.669 с.

6. Бродский А. К. Краткий курс общей экологии: учебное пособие. СПб.: ДЕАН. 2000. $224 \mathrm{c}$.

7. Волков В.Т., Смирнов Г.В., Медведев М.А., Волкова Н.Н. Нанобактерия (перспективы исследований). Томск: Твердыня, 2003. 359 с.

8. Воскресенская О.Л., Скочилова Е.А., Копылова Т.И., Алябышева Е.А., Сарбаева Е.В. Организм и среда: фракториальная экология: учебное пособие. Йошкар-Ола, 2005. $180 \mathrm{c}$.

9. Евстропов В.М. Опасные природные и производственные процессы. Медицина катастроф: учебное пособие. Ростов-н/Д, 2005. 68 с.

10.Евстропов В.М. Приготовление клеточной взвеси на стекле // Клиническая лабораторная диагностика.1983. № 2. С. 54.

11. Способ определения трансформированных клеток: патент на изобретение Рос. Федерация № 2117946: G01N 33/53/ B.M. Евстропов. № 97107888/14; заявл. 26.05.97; опубл. 20.08.98, Бюл. № 23.1998. 6 с.

12.Евстропов В.М. Влияние температурного фрактора на спонтанное контактное взаимодействие лимфоцитов с гранулоцитами // Живые и биокосные системы. 2016. № 15. C. 51. URL: http://www.jbks.ru/archive/issue-15/article-5 (дата посещения 21.08.2017).

13. Ермаков В.В. Развитие учения о природных и техногенных биогеохимических провинциях как основы современных биосферных исследований. Микроэлементы в СССР. Рига: Зинатне, 1992. Т. 32. С. 68-75.

14.Князева Е.Н. Перспективы экологического эволюционизма // Вестник Московского государственного гуманитарного университета им. М.А. Шолохова. Серия Социально-экологические технологии. 2013. № 1. С. 13-25.

15. Князева E.H. Экологическая культура в международной парадигме развития // Социально-экологические технологии. 2013. Вып. 1. С. 13-25.

16. Ковальский В.В. Геохимическая экология. М.: Наука, 1974. 280 с.

17. Козлов Ю.П. Современные проблемы фризико-химической экологии // Известия Иркутского государственного университета. Серия Биология. Экология. 2008. Т. 1. № 2. C. $115-119$.

18. Круть И.В., Забелин И.М. Очерки истории представлений о взаимоотношении природы и общества. М.: Наука, 1988. 416 с.

19. Наумов Н.П. Экология животных.2-е изд. М.: Высшая школа,1963. 619 с. 
20. Одум Ю. Основы экологии. М.: Мир, 1975. 740 с.

21. Остроумов C.A. Подходы к очищению и оздоровлению водных объектов (фиторемедиация, биоремедиация, зооремедиация) в связи с теорией полифункциональной роли биоты в самоочищении вод // Вода: технология и экология. 2007. № 2. С. 49-69.

22. Павловский Е.Н. Организм как среда обитания // Природа. 1934. № 1. С. 80-91.

23. Розенберг Г.С., Рянский Ф.Н. Теоретическая и прикладная экология: учебное пособие. 2-е изд. Нижневартовск, 2005. 292 с.

24. Святова Н.В., Васильев С.В., Влияние экологических условий проживания на содержание химических элементов в организме // Ученые записки Казанского филиала "Российского государственного университета правосудия". 2016. Т. 12. С. 417-433.

25. Симонова О.И., Долговых С.В. Биология с основами экологии: учебнометодический комплекс (для студентов, обучающихся по специальности 020101 «Химия»). Горно-Алтайск: РИО ГАГУ, 2009. 167 с.

26. Скальный А.В. Химические элементы в физиологии и экологии человека. М.: Издательский дом «ОНИКС 21 век»: Мир, 2004. 216 с.

27. Смирнов Г.В., Смирнов Д.Г. Нанобактерия и статистика некоторых заболеваний. Сахаровские чтения 2005 года: экологические проблемы XXI века: Матер. V Междунар. научн. конфер. Минск, 2005. Ч. 1. С. 156-157.

28. Смирнов Д.Г., Волкова Н.Н. Нанобактерии - как биоиндикатор экологического неблагополучия среды или заболевания человека // Известия Томского политехнического университета. 2006. Т. 309. № 8. С.179-182.

29. Степановских А.С. Экология. Учебник для вузов М.: ЮНИТИ-ДАНА, 2001. 703 с.

30.Тарасова Т.Ф., Байтелова А.И., Ермолаева А.А. Оценка воздействия микроорганизмов на качество поверхностных вод // Вестник Оренбургского государственного университета. 2011. № 12 (131). С. 361-362.

31.Хабибуллин В.Ф. К спецификации понятий «среда жизни» и «сфреры жизни» // Вестник Томского государственного университета. 2013. Т.18. Вып. 3. С. 838-841.

32. Хотулёва О.В., Егорова Г.В., Зыков И.Е. Пособие для практических занятий. Орехово-Зуево, 2017. С.49-56.

33. Чернова Н.М., Былова А.М. Общая экология. Учебник. М.: Дрофра, 2004. 416 с.

34. Экология: учебник. Изд. 2-е. / В.Н. Большаков, В.В. Качак, В.Г. Кобер и др. М.: Логос, 2005. 504 c.

35. Clarke G.L. Elements of Ecology. N.Y.; L., 1954. 534 p.

36. Margalef R. Perspectives in Ecological Theory. Chicago, 1969. III p. Margalef, 341.

37. Fretwell, Stephen D. The Impact of Robert MacArthur on Ecology. Annual Review of Ecology and Systematics. 1975. № 6. p. 1-13.

38. Haeckel E. Generelle Morphologie der Organismen. Allgemeine Grund-zuge der organischen Formen-Wissenschaft, mechanisch begrundet durch die von Charles Darwin reformirte Descendenz-Theorie. Berlin, 1866. $318 \mathrm{~s}$.

39. Sommer A.P., Hassinen H.I., Kajander E.O. Lightinduced replication of nanobacteria: a preliminary report. Journal of Clinical Laser Medicine \& Surgery. 2002; 5: 241.

40.Brown F., Burton D., Doherty P., Mekalanos J., Norrby EÇiftçioglu N., Kuronen I., Ȧkerman K., Hiltunen E., Laukkanen J., Kajander E.O.(1997) in Vaccines 97, eds Brown F., Burton D., Doherty P., Mekalanos J., Norrby E. (Cold Spring Harbor Lab. Press, Cold Spring Harbor, NY), pp 99-103. 


\section{References}

1. Avtsyn A.P., Zhavoronkov A.A., Rish M.A., Strochkova L.S. Mikroelementozy cheloveka: etiologiya, klassifikatsiya, organopatologiya. M.: Meditsina. [Human microelementoses: etiology, classification, organopathology. Moscow: Medicine]. 1991. 496 p. (in Russian).

2. Alekseyev A.N., Kondrashova Z.N. Organizm chlenistonogikh kak sreda obitaniya vozbuditeley. Sverdlovsk: UNTS AN SSSR. [Arthropod organism as a habitat for pathogens. Sverdlovsk: Ural Branch of the Russian Academy of Sciences]. 1985.180 p. (in Russian).

3. Bezuglova O.S., Orlov D.S. Biogeokhimiya. Rostov n/D: Feniks. [Biogeochemistry. Rostov-on-Don: Phoenix]. 2000. 320 p. (in Russian).

4. Belov S.V. Evolyutsiya organizmov i osnovnoy paradoks ekologii. Ekologicheskiye sistemy i pribory. [The evolution of organisms and the main paradox of ecology. Ecological systems and devices]. 2018. No. 2. pp. 3-9 (in Russian).

5. Bigon M., Kharper Dzh., Taunsend K. Ekologiya. Osobi, populyatsii i soobshchestva. M.: «Mir». [Ecology. Individuals, populations, and communities. Moscow: Mir]. 1989. V. 1. 669 p. (in Russian).

6. Brodskiy A.K. Kratkiy kurs obshchey ekologii: uchebnoye posobiye.SPb.: DEAN. [A short course in general ecology: a training manual. St. Petersburg: DEAN.]. 2000. 224 p. (in Russian).

7. Volkov V.T., Smirnov G.V., Medvedev M.A., Volkova N.N. Nanobakteriya (perspektivy issledovaniy). Tomsk: Tverdynya. [Nanobacteria (research prospects). Tomsk: Stronghold]. 2003. 359 p. (in Russian).

8. Voskresenskaya O.L., Skochilova Ye.A., Kopylova T.I., Alyabysheva Ye.A., Sarbayeva Ye.V. Organizm i sreda: faktorialnaya ekologiya: uchebnoye posobiye. Yoshkar-Ola. [Organism and environment: factorial ecology: a training manual. Yoshkar-Ola]. 2005. 180 p. (in Russian).

9. Yevstropov V.M. Opasnyye prirodnyye i proizvodstvennyye protsessy. Meditsina katastrof: uchebnoye posobiye. Rostov-n/D. [Hazardous natural and industrial processes. Disaster medicine: a training manual. Rostov-on-Don]. 2005. 68 p. (in Russian).

10. Yevstropov V.M. Prigotovleniye kletochnoy vzvesi na stekle. Klinicheskaya laboratornaya diagnostika. [Preparation of cell suspension on glass. Clinical laboratory diagnostics].1983. No. 2. 54 p. (in Russian).

11. Sposob opredeleniya transformirovannykh kletok: patent na izobreteniye Ros. Federatsiya. [Method for the determination of transformed cells: patent for the invention of Russian Federation]. №2117946: G01N 33/53/V. M. Yevstropov. No. 97107888/14; zayavl. [declared] 26.05.97; opubl. [published]. 20.08.98, Byul. [Бюл]. No. 23.1998. 6 p. (in Russian).

12. Yevstropov V.M. Vliyaniye temperaturnogo faktora na spontannoye kontaktnoye vzaimodeystviye limfotsitov s granulotsitami. Zhivyye i biokosnyye sistemy. [The influence of the temperature factor on the spontaneous contact interaction of lymphocytes with granulocytes. Living and biocos systems]. 2016. No. 15. 51 p. Available at: http://www.jbks.ru/archive/issue-15/article-5 (Accessed 21.08.2017).

13. Yermakov V.V. Razvitiye ucheniya o prirodnykh i tekhnogennykh biogeokhimicheskikh provintsiyakh kak osnovy sovremennykh biosfernykh issledovaniy. Mikroelementy $v$ SSSR. [The development of the doctrine of natural and technogenic biogeochemical provinces as the basis of modern biosphere research. Microelements in the USSR]. Riga: Zinatne. 1992. V. 32. pp. 68-75 (in Russian). 
14. Knyazeva Ye.N. Perspektivy ekologicheskogo evolyutsionizma. Vestnik Moskovskogo gosudarstvennogo gumanitarnogo universiteta im. M.A. Sholokhova. Seriya: Sotsial'no-ekologicheskiye tekhnologii. [Prospects for Environmental Evolutionism. Bulletin of Moscow State University for the Humanities M.A. Sholokhov. Series: Social and Environmental Technologies]. 2013. No. 1. pp. 13-25 (in Russian).

15. Knyazeva Ye.N. Ekologicheskaya kultura $v$ mezhdunarodnoy paradigme razvitiya. Sotsialno-ekologicheskiye tekhnologii. [Ecological culture in the international development paradigm. Social and environmental technology]. 2013. Issue 1. pp. 1325 (in Russian).

16. Kovalskiy V.V. Geokhimicheskaya ekologiya. M.: Nauka. [Geochemical ecology. Moscow: Science]. 1974. 280 p. (in Russian).

17. Kozlov Y.P. Sovremennyye problemy fiziko-khimicheskoy ekologii. Izvestiya Irkutskogo gosudarstvennogo universiteta. Seriya Biologiya. Ekologiya. [Modern problems of physical and chemical ecology. News of Irkutsk State University. Series "Biology. Ecology"]. 2008. V. 1. No. 2. pp. 115-119 (in Russian).

18. Krut I.V., Zabelin I.M. Ocherki istorii predstavleniy o vzaimootnoshenii prirody i obshchestva. M : Nauka. [Essays on the history of ideas about the relationship between nature and society. Moscow: Science]. 1988. 416 p. (in Russian).

19. Naumov N.P. Ekologiya zhivotnykh.2-ye izd. M.: Vysshaya shkola. [Animal Ecology. 2nd ed. Moscow: Higher School]. 1963. 619 p. (in Russian).

20. Odum Y. Osnovy ekologii. M.: Mir. [Fundamentals of Ecology. Moscow: World]. 1975. 740 p. (in Russian).

21. Ostroumov S.A. Podkhody k ochishcheniyu i ozdorovleniyu vodnykh ob"yektov (fitoremediatsiya, bioremediatsiya, zooremediatsiya) $v$ svyazi $s$ teoriyey polifunktsional'noy roli bioty $v$ samoochishchenii vod. Voda: tekhnologiya i ekologiya. [Approaches to the purification and rehabilitation of water bodies (phytoremediation, bioremediation, zoomediation) in connection with the theory of the multifunctional role of biota in water self-purification. Water: technology and ecology]. 2007. No. 2. pp. 4969 (in Russian).

22. Pavlovskiy Ye.N. Organizm kak sreda obitaniya. Priroda. [The organism as a habitat. Nature.]. 1934. No. 1. pp. 80-91 (in Russian).

23. Rozenberg G.S., Ryanskiy F.N. Teoreticheskaya i prikladnaya ekologiya: uchebnoye posobiye. 2-ye izd. Nizhnevartovsk. [Theoretical and applied ecology: a training manual. 2nd ed. Nizhnevartovsk]. 2005. 292 p. (in Russian).

24. Svyatova N.V., Vasil'yev S.V., Vliyaniye ekologicheskikh usloviy prozhivaniya na soderzhaniye khimicheskikh elementov v organizme. Uchenyye zapiski Kazanskogo filiala "Rossiyskogo gosudarstvennogo universiteta pravosudiya". [Influence of environmental living conditions on the content of chemical elements in the body. Scientific notes of the Kazan branch of the Russian State University of Justice]. 2016. V. 12. pp. 417-433 (in Russian).

25. Simonova O.I., Dolgovykh S.V. Biologiya s osnovami ekologii: uchebno-metodicheskiy kompleks (dlya studentov, obuchayushchikhsya po spetsial'nosti 020101 «Khimiya»). [Biology with the basics of ecology: an educational and methodical complex (for students studying in the specialty 020101 "Chemistry"]. Gorno-Altaysk: RIO GAGU. 2009. 167 p. (in Russian).

26. Skalnyy A.V. Khimicheskiye elementy v fiziologii i ekologii cheloveka. M.: Izdatel'skiy dom «ONIKS 21 vek»: Mir. [Chemical elements in the physiology and ecology of man. Moscow: Publishing house "ONIX 21 Century": World]. 2004. 216 p. (in Russian).

27. Smirnov G.V., Smirnov D.G. Nanobakteriya i statistika nekotorykh zabolevaniy. Sakharovskiye chteniya 2005 goda: ekologicheskiye problemy XXI veka: Mater. V 
Mezhdunar. nauchn. konfer. [Nanobacteria and statistics of some diseases. Sakharov Readings of 2005: Environmental Problems of the 21st Century: the proceedings of $\mathrm{V}$ International scientific conference]. Minsk. 2005. P. 1. pp. 156-157 (in Russian).

28. Smirnov D.G., Volkova N.N. Nanobakterii - kak bioindikator ekologicheskogo neblagopoluchiya sredy ili zabolevaniya cheloveka. Izvestiya Tomskogo politekhnicheskogo universiteta. [Nanobacteria - as a bio-indicator of environmental dysfunction of an environment or human disease. Bulletin of the Tomsk Polytechnic University]. 2006. V. 309. No. 8. pp.179-182 (in Russian).

29. Stepanovskikh A.S. Ecology. Textbook for high schools M: UNITY-DANA. [Ecology. Textbook for high schools. Moscow: UNITY-DANA.]. 2001. 703 p. (in Russian).

30. Tarasova T.F., Baytelova A.I., Yermolayeva A.A. Otsenka vozdeystviya mikroorganizmov na kachestvo poverkhnostnykh vod. Vestnik Orenburgskogo gosudarstvennogo universiteta. [Assessment of the impact of microorganisms on surface water quality. Bulletin of the Orenburg State University]. 2011. No. 12 (131). pp. 361-362 (in Russian).

31. Khabibullin V.F. K spetsifikatsii ponyatiy «sreda zhizni» i «sfery zhizni». Vestnik Tomskogo gosudarstvennogo universiteta. [To the specification of the concepts "environment of life" and "sphere of life". Bulletin of Tomsk State University]. 2013. V.18, Issue 3. pp. 838-841 (in Russian).

32. Khotulova O.V., Yegorova G.V., Zykov I.Ye. Posobiye dlya prakticheskikh zanyatiy. Orekhovo-Zuyevo, 2017. [Manual for practical exercises. Orekhovo-Zuevo, 2017]. pp. 49-56 (in Russian).

33. Chernova N.M., Bylova A.M. Obshchaya ekologiya. Uchebnik. M.: Drofa. [General ecology. Textbook. Moscow: Drofa]. 2004. 416 p. (in Russian).

34. Ekologiya: uchebnik. Izd.2-ye. [Ecology: a textbook. Vol. 2.]. V.N. Bol'shakov, V.V. Kachak, V.G. Kober i dr. M.: Logos. [et al. Moscow: Logos]. 2005. 504 p. (in Russian).

35. Clarke G.L. Elements of Ecology. N.Y.; L., 1954. 534 p.

36. Margalef R. Perspectives in Ecological Theory. Chicago, 1969. Ill p. Margalef, 341.

37. Fretwell, Stephen D. The Impact of Robert MacArthur on Ecology. Annual Review of Ecology and Systematics. 1975. № 6, pp. 1-13.

38. Haeckel E. Generelle Morphologie der Organismen. Allgemeine Grund-zuge der organischen Formen-Wissenschaft, mechanisch begrundet durch die von Charles Darwin reformirte Descendenz-Theorie. Berlin, 1866. 318 p.

39. Sommer A.P., Hassinen H.I., Kajander E.O. Lightinduced replication of nanobacteria: a preliminary report. Journal of Clinical Laser Medicine \& Surgery. 2002; 5: 241.

40. Brown F., Burton D., Doherty P., Mekalanos J., Norrby EÇiftçioglu N., Kuronen I., Åkerman K., Hiltunen E., Laukkanen J., Kajander E.O. (1997) in Vaccines 97, eds Brown F., Burton D., Doherty P., Mekalanos J., Norrby E. (Cold Spring Harbor Lab. Press, Cold Spring Harbor, NY), pp. 99-103. 